\title{
Information System for Monitoring the Movement of Medicines as a Means of Increasing the Effectiveness of Pharmacovigilance
}

\author{
Filippova O.V. Greibo S.V. Pronkin N.N. \\ First Moscow State Medical I.M. Sechenov University of the Ministry of Healthcare of the Russian Federation (Sechenov \\ University), Moscow, Russia \\ *Corresponding author. Email: pr_nick@mail.ru
}

\begin{abstract}
One of the problems of medical therapy is the possibility of adverse side effects of medicines. According to the recommendations of the World Health Organization, 60 reports of adverse reactions per 100 thousand people are considered the norm. Moreover, undesirable effects can be caused by various reasons, including a violation of the storage conditions of medicines at various stages of treatment. In Russia alone, more than 7 billion packages of medicines are produced and imported from other countries per year. The development of modern information technologies in medicine made it possible to introduce an information system for monitoring movement, which makes it possible to track each package of medicines. The article formulates the main possibilities of using a monitoring system for the needs of pharmacovigilance. The alleged causes of the appearance of undesirable effects during the use of medicines and the features of their identification, as well as regulatory measures that are recommended to be taken, are determined. Possible ways of using the monitoring system to increase the safety of medicines therapy are given.
\end{abstract}

Keywords: information system for monitoring the movement of medicines, methods for automatic identification of objects, medicine safety, pharmacovigilance

\section{INTRODUCTION}

All medicines in circulation in the Russian Federation are subject to monitoring of efficacy and safety in order to identify possible negative consequences of their use [1,2]. Monitoring the safety of medicines or pharmacovigilance (Pharmacovigilance), is a science and activity aimed at identifying, evaluating and preventing unwanted reactions or any other possible problems associated with medicines $[1,3,4]$.

Pharmacovigilance is aimed at improving the safety and quality of patient care. Pharmacovigilance is carried out by the authorized federal executive body: Roszdravnadzor [1].

Effective pharmacovigilance requires collaboration between the executive branch and pharmaceutical companies, medical organizations, doctors, scientists, toxicological control centers, the media, and patients.

Holders of medicine registration certificates are required to receive, record, process, analyze and store incoming messages about side effects, adverse reactions, serious unwanted and unforeseen adverse reactions when using them, about the features of their interaction with other medicines, individual intolerance, and about other facts and circumstances that pose a threat to human life or health or affecting a change in the attitude of expected benefit to the possible risk of their use [3-7].
In order to ensure the safety control of the use of medicines, responsible employees of pharmaceutical companies constantly monitor information regarding adverse reactions and medical efficacy. The information comes from doctors, pharmaceutical workers, patients. Regular monitoring of specialized medical literature is also carried out. All safety information received is entered into the database of the manufacturer, and also sent to the Federal Service for Supervision of Healthcare (Roszdravnadzor) through an automated system for electronic recording of information about unwanted reactions (www.roszdravnadzor.ru).

When identifying information about serious adverse reactions and unforeseen adverse reactions, as well as other facts and circumstances affecting the change in the ratio of the expected benefit to the possible risk of using medicines, measures must be taken to eliminate the negative consequences of the use of medicines and prevent harm to life or human health.

There is a fairly wide range of regulatory measures in identifying medicines safety problems. This is the deregistration of medicine, and the suspension of treatment $[1,5]$. It is possible to amend the instructions, the requirement for additional clinical / preclinical studies [3]. Of course, the choice of measures is determined by the reason why the medicine caused an undesirable reaction. Changes in doses, methods of use, indications and limitations of the use of medicines are justified if, in the 
process of applying the medicine in the clinic, its new properties are revealed. For example, post-marketing studies have found that prolonged use of hydrochlorothiazide leads to an increased risk of skin cancer. This fact led to the recommendations of the regulator to change the Instructions for the use of medicines containing hydrochlorothiazide, namely to enter the relevant information, as well as recommendations to protect the skin from sunlight during treatment with the medicine [8].

On the other hand, if an adverse reaction is detected, which is not particularly reflected in the Instructions for medical use, it is likely that the cause of this effect is the non-compliance of the medicine with the requirements for product quality. The reasons for such deviations are not homogeneous (Table 1): they can be associated both with manufacturing errors and with violations of the storage conditions for medicines at various stages of the supply chain. To identify the link responsible for the violation of the quality of the medicine is important both to prevent the recurrence of such problems and to identify the perpetrators. The latter, according to the legislation of the Russian Federation, can bear both administrative and criminal liability [10].

The most dangerous are deviations in the quality of medicines associated with a violation of the technological process in production. Contamination of the medicines with undesirable impurities, for example, can lead to the death of patients, significantly increasing the risk of unwanted adverse reactions. In addition, problems at factories require suspension of circulation and recall of at least the entire series of medicines. If the violations are associated with improper organization of production at a specific production site, it is possible to suspend the manufacturer's license, corrective measures to change SWSs, etc.

If quality violations have arisen as a result of improper storage and representatives of the wholesale or retail link of the supply chain are to blame, the consignment may be recalled. Violation of the rules for storage of medicines refers to gross violations of licensed activities, therefore, the regulator will monitor the storage conditions and eliminate deficiencies and decide on the punishment of those responsible.

The option is possible when the responsibility for adverse events lies with the consumer of medicines, who himself created the conditions for harming his health. Firstly, there may be a violation of storage rules for medicines (for example, non-compliance with temperature conditions), which is observed quite often. Secondly, there may be a violation of the rules for taking the medicine (dose, frequency of administration, tolerance of irrational medicines interactions, etc.). The latter can be triggered by the fact that the patient did not understand the contents of the Instructions for medical use. If a similar problem is repeated, this may require amendments to the Instruction.

Table 1 Causes of Adverse Events

\begin{tabular}{|c|c|c|c|c|}
\hline & \multicolumn{3}{|c|}{ Cause of Adverse Events } & \multirow[b]{2}{*}{$\begin{array}{l}\text { Improper storage / use } \\
\text { of medicines by the } \\
\text { end user }\end{array}$} \\
\hline & Medicine properties & $\begin{array}{l}\text { Violations of production } \\
\text { technology }\end{array}$ & $\begin{array}{l}\text { Change in the } \\
\text { properties of } \\
\text { medicines due to } \\
\text { violations of storage } \\
\text { conditions at different } \\
\text { stages of the } \\
\text { conductive circuit }\end{array}$ & \\
\hline $\begin{array}{l}\text { Message } \\
\text { Features }\end{array}$ & $\begin{array}{l}\text { Messages accumulate during } \\
\text { the entire period of the } \\
\text { existence of medicines on the } \\
\text { market } \\
\text { Associated with medicines of } \\
\text { different series }\end{array}$ & $\begin{array}{l}\text { Messages are associated } \\
\text { with medicines of one series } \\
\text { or series produced in a short } \\
\text { time period }\end{array}$ & $\begin{array}{l}\text { Messages are related } \\
\text { to the medicines of } \\
\text { part of the series } \\
\text { (batch or several } \\
\text { batches) }\end{array}$ & $\begin{array}{l}\text { Single messages when } \\
\text { using medicines of } \\
\text { different series and } \\
\text { parties }\end{array}$ \\
\hline $\begin{array}{l}\text { Regulatory } \\
\text { measures }\end{array}$ & $\begin{array}{l}\text { Suspension of treatment for } \\
\text { additional clinical trials } \\
\text { Amendments to the } \\
\text { Instructions for the use of } \\
\text { medicines } \\
\text { Medicine withdrawal from the } \\
\text { market }\end{array}$ & $\begin{array}{l}\text { Recall of medicine series } \\
\text { from the market }\end{array}$ & $\begin{array}{l}\text { Recall of a series } \\
\text { (batch) of medicines } \\
\text { from the market }\end{array}$ & $\begin{array}{l}\text { When the situation } \\
\text { repeats, changes to the } \\
\text { Instructions for use, } \\
\text { change of product } \\
\text { labeling } \\
\text { It is possible to change } \\
\text { the packaging, supply } \\
\text { the medicine } \\
\text { dispenser, etc. }\end{array}$ \\
\hline $\begin{array}{l}\text { Responsible } \\
\text { person }\end{array}$ & $\begin{array}{l}\text { Medicine creator } \\
\text { A person responsible for the } \\
\text { registration of the medicine }\end{array}$ & $\begin{array}{l}\text { Medicine manufacturer } \\
\text { (Quality Authorized Person) }\end{array}$ & $\begin{array}{l}\text { Wholesale or retail } \\
\text { pharmaceutical } \\
\text { organization } \\
\text { (responsible for } \\
\text { quality) }\end{array}$ & $\begin{array}{l}\text { Consumer } \\
\text { The manufacturer of } \\
\text { the medicine may be } \\
\text { liable if the } \\
\text { instructions for } \\
\text { medical use are not } \\
\text { drawn up correctly }\end{array}$ \\
\hline
\end{tabular}


It should be recognized that determining the causes of inadequate quality of medicines is not always an easy and quick task. It takes time both to conduct an analysis of the compliance of the medicinal product with quality standards, and to clarify the causes of these deviations. One of the possible ways to speed up decision making is to use modern information systems.

At present, a Motion Monitoring Information System (information system) is being introduced in Russia, which is designed to organize continuous monitoring of the movement of medicines from the manufacturer to the final consumer. The information system includes the use of individual (group) coded labeling and identification of packages of medicines in order to ensure effective quality control of medicines in circulation and to combat their falsification [10].

It seems interesting to use the Information System for the needs of pharmacovigilance. If before the packaging of a medicine of one series of manufacture was identical, then with the introduction of this system a control identification mark on each packaging not only allows you to distinguish between each packaging of a medicine, but also in monitoring with the information system to monitor it in the subjects of medicine circulation. This makes it possible to quickly monitor the source of each package and to track the supply chain along which the package moved. With the receipt of several reports of undesirable side effects on one medicine, thanks to the Information System, it is quite simple to track whether the packages of the "problematic" medicine belong to one series or one batch. If undesirable reactions are associated with medicines of one series, this requires not only the suspension of medicine circulation in this series but also an urgent check of the production conditions. Moreover, thanks to the Information System, it is possible to control the appearance of undesirable reactions to medicines passing through one wholesale or retail provider. The increase in the frequency of undesirable reactions, including unexpected ones, from different medicines that have the same channels for entering the market, should be considered as a reason for strengthening control measures for participants in the supply chain and their observance of medicine storage regimes.

The result of using the Information System for the needs of pharmacovigilance will be to improve the quality of medicine supply for the population of the Russian Federation, which is one of the priorities of national health care [11].

\section{CONCLUSION}

The use of the Information System for the needs of pharmacovigilance should lead to the following results: - a significant reduction in the threats to life and health of the population of the Russian Federation that may cause substandard medicines;
- the creation of a mechanism for monitoring the frequency of adverse reactions to the use of medicines depending on the series and lot of the medicine, followed by the operational regulation of the circulation of medicines, including suspension of circulation and withdrawal of medicines from the market;

- continuous operational control of the market and its individual segments, on the basis of which it is possible to increase the effectiveness of control measures in the pharmaceutical market;

- the possibility of developing mechanisms for the prompt withdrawal of medicines from circulation throughout the Russian Federation;

- increasing the effectiveness of federal state supervision in the field of medicines circulation.

The marking system allows access to an unlimited quantity of persons to the database. The consumer can personally verify the legality of finding the medicines in circulation, as well as enter data on the undesirable effects associated with the use of a specific unit of the medicine. This will allow more widespread involvement of end consumers in the collection of information for the needs of pharmacovigilance.

\section{REFERENCES}

[1] Federal'nyy zakon ot 12.04.2010 №61-FZ "Ob obrashchenii lekarstvennykh sredstv"

[2] Soglasheniye o yedinykh printsipakh i pravilakh obrashcheniya lekarstvennykh sredstv $\mathrm{v}$ ramkakh Yevraziyskogo ekonomicheskogo soyuza

[3] Prikaz Roszdravnadzora №1071 ot 15.02.2017 «Ob utverzhdenii poryadka osushchestvleniya farmakonadzora»

[4] Pravila Nadlezhashchey Praktiki Farmakonadzora (GVP), utverzhdonnymi Resheniyem Soveta Yevraziyskoy Ekonomicheskoy Komissii ot 03.11. 2016 №87 (GVP YEAES) Prikaz Minzdrava Rossii ot 07.09.2015 N 5539 «Ob utverzhdenii poryadka osushchestvleniya vyborochnogo kontrolya kachestva LS dlya meditsinskogo primeneniya»

[5] Prikaz Ministerstva zdravookhraneniya RF ot 14 noyabrya 2018 g. N 777n "Ob utverzhdenii Poryadka priostanovleniya primeneniya lekarstvennogo preparata dlya meditsinskogo primeneniya"

[6] ICH Harmonized Tripartite Guideline E2C (R1) "Clinical safety data management: periodic safety update reports for marketed drugs"

[7] ICH Harmonized Tripartite Guideline E2C (R2)"Periodic Risk-Benefit Evaluation Report (PBER)" 
[8] Elektronnyy resurs. URL: https://www.ema.europa.eu/documents/pracrecommendation/prac-recommendations-signalsadopted-3-6-september-2018-prac-meeting_en-0.pdf

[9] UK RF, Stat'ya 238 Proizvodstvo, khraneniye, perevozka libo sbyt tovarov i produktsii, vypolneniye rabot ili okazaniye uslug, ne otvechayushchikh trebovaniyam bezopasnosti

[10] Prikaz Minzdravsotsrazvitiya RF ot 26.08.2010 g. №757n "Ob utverzhdenii Poryadka osushchestvleniya monitoringa bezopasnosti lekarstvennykh preparatov dlya meditsinskogo primeneniya, registratsii pobochnykh deystviy, ser'yeznykh nezhelatel'nykh reaktsiy, nepredvidennykh nezhelatel'nykh reaktsiy pri primenenii lekarstvennykh preparatov dlya meditsinskogo primeneniya";

[11] Prikaz Minzdrava Rossii ot 13.02.2013 N 66 (red. ot 07.04.2016) "Ob utverzhdenii Strategii lekarstvennogo obespecheniya naseleniya Rossiyskoy Federatsii na period do 2025 goda i plana yeye realizatsii".

[12] A. Komarova, L. Tsvetkova, S. Kozlovskaya, N. Pronkin, Organisational educational systems and intelligence business systems in entrepreneurship education. Journal of Entrepreneurship Education. 2019. T. 22. № 5. C. 15.

[13] A. Kurilova, E. Lysenko, N. Pronkin, K. Mukhin, D. Syromyatnikov, The impact of strategic outsourcing on the interaction market in entrepreneurship education. Journal of Entrepreneurship Education. 2019. T. 22. № 4. C. 15 . 